\title{
Correction: Regional metastatic paraganglioma of the bladder: a rare cause of myocardial infarction, reversible cardiomyopathy and an intracardiac thrombus
}

Kazakova V, Kadamkulam Syriac A, et al. Regional metastatic paraganglioma of the bladder: a rare cause of myocardial infarction, reversible cardiomyopathy and an intracardiac thrombus. BMJ Case Rep CP 2020;13:e233731.

This article was previously published with an error in the Acknowledgement statement. The updated Acknowledgement statement is stated below:

The authors wish to express our deepest gratitude to Dr Olga Kozyreva who reviewed our manuscript and ensured its accuracy from oncologicalstand point. The authors also wish to acknowledge the input of Dr Lana Tsao and Dr Shruti Hegde who were closely involved in the diagnosis and care of this patient andpresented the case at our hospital conference as well as at the American College ofCardiology 2019 conference.

(C) Author(s) (or their employer(s)) 2020. No commercial re-use. See rights and permissions. Published by BMJ.

BMJ Case Rep 2020;13:e233731corr1. doi:10.1136/bcr-2019-233731corr1

D) Check for updates

Copyright 2020 BMJ Publishing Group. All rights reserved. For permission to reuse any of this content visit https://www.bmj.com/company/products-services/rights-and-licensing/permissions/

BMJ Case Report Fellows may re-use this article for personal use and teaching without any further permission.

Become a Fellow of BMJ Case Reports today and you can:

- Submit as many cases as you like

Enjoy fast sympathetic peer review and rapid publication of accepted articles

- Access all the published articles

Re-use any of the published material for personal use and teaching without further permission

Customer Service

If you have any further queries about your subscription, please contact our customer services team on $+44(0)$ 2071111105 or via email at support@bmj.com.

Visit casereports.bmj.com for more articles like this and to become a Fellow 